\title{
Managerial Ownership And Dividend Policy In The U.S. Banking Industry
}

M. Cary Collins, Bryant University, USA

Amitabh S. Dutta, Florida Institute of Technology, USA

James W. Wansley, University of Tennessee, USA

\begin{abstract}
This paper examines a sample of U.S. Bank Holding Companies (BHCs) to determine if there is a relationship between managerial equity ownership (insider holdings) and the level of dividends paid out by the BHC. Given the findings of prior research, the analysis is performed using TwoStage Least Squares (2SLS) regression with three equations. The three dependent variables are DIVPAY (dividend payout), DEBT (total liabilities over total consolidated assets) and INSIDER (percentage of common stock held by officers and directors). This study finds that insider holdings has a non-linear relation with dividend payout. Initially, there is a significant negative relation between the level of insider holdings and the level of dividends paid. However, higher levels of insider holdings show a positive relation with the level of dividends paid.
\end{abstract}

Keywords: U.S. BHCs; Managerial equity ownership; Insider holdings; Dividend payout

\section{INTRODUCTION}

enerally, studies that examine the relation between ownership structure and corporate policy for industrial firms rarely examine the effect of the level of managerial ownership of banks on their debt structure and dividend policy. In fact, prior research on corporate policy usually truncates the sample by deleting all firms from regulated industries such as banks and utilities [Bradley, Jarrell and Kim (1984)]. The logic for exempting banks and utilities often revolves around the very high historical levels of regulation associated with each entity type - and the concomitantly low levels of managerial discretion. For utilities, the reasoning further suggests that shareholdings are routinely atomistic, even among insiders. On the other hand, banks - or more correctly, bank holding companies (BHCs) - now frequently possess groups of insiders with significant shareholdings, particularly among regional BHCs [Collins, Blackwell and Sinkey (1995)]. Furthermore, BHCs have experienced growth in product, market and service offerings, yielding a much higher level of managerial discretion than previously existed [Collins, Blackwell and Sinkey (1994)].

This study examines whether the level of insider holdings may be a possible determinant of the level of dividend payout in a sample of U.S. bank holding companies (BHCs) over the period 1994 to 1997.

The paper is structured as follows. Section I presents a review of the relevant literature. Section II discusses the data and methodology. Section III contains the results of this study. Section IV summarizes and concludes the paper.

\section{LITERATURE REVIEW}

Agency theory states that managers of firms are likely to engage in non-value maximizing (NVM) behavior. Jensen and Meckling (1976) theorized that the value of the firm would be decreased by the agency costs incurred due to NVM managers. However, if a manager's personal wealth were linked to the price of the firm's common equity, these agency costs could be reduced. Thus, managerial ownership of equity (insider holdings) could serve as an agency-cost reducing mechanism, increasing the value of the firm. 
The relation between insider holdings and the market value of a firm is not a linear relationship, as seen by Morck, Shleifer and Vishny (1988) (MSV) in examining a sample of Fortune 500 firms. For example, they find that the market value of the firm first increases as insider holdings increase from 0 to $5 \%$. Then, as insider holdings increase from 5 to $25 \%$, the market value of the firm decreases. Finally, as insider holdings increase beyond $25 \%$, the market value of the firms again increases. The authors explain their results as evidence of managerial entrenchment ${ }^{1}$. While lower and higher levels of insider holdings support the notion of insider holdings leading to lower agency costs, the middle level of ownership is a range over which the benefits of NVM behavior on the part of managers exceeds the costs incurred by the lower market price of equity.

The nature of this non-linearity may be sample and/or time dependent. Wruck (1989) finds that for a sample of firms announcing a private equity sale, firm value increases significantly for firms with low and high levels of insider holdings. In a middle range of insider holdings, firm value decreases significantly. The author confirms the range of "entrenchment" reported by MSV. However, McConnell and Servaes (1990) in an extension of MSV report a curvilinear relation between insider holdings and firm value, as opposed to the piece-wise linear relation documented by MSV. These studies, though, do not include any regulated firms in their respective samples.

Healy and Palepu (1989) suggest that the two decisions of managers that generally have a significant impact on stock price are: (1) Choice of how much debt to hold in the firms' capital structure, and (2) Choice of how much of earnings to pay out as dividends, if any.

Thus, researchers have also argued that debt and dividend policies serve as signals of firm quality or convey information about firms to the market. Insider holdings, by decreasing NVM behavior of managers, have been looked on as a substitute signal of firm quality. In fact, researchers have examined the relation between these three variables - insider holdings, dividends and debt to determine whether they serve as substitute or complementary signals. Traditionally, it has been assumed that regulators in the banking industry perform the role that corporate policy would serve in unregulated firms. This monitoring proxy would imply that for banks none of these variables, namely insider holdings, debt and dividends, need serve as signals of firm quality. The dealing of regulators with individual banks would convey sufficient information to the market for determining the quality of each bank.

However, Gorton and Rosen (1995), in examining the decline of banking in the United States, present a model that illustrates how managerial ownership of banks can lead to entrenchment - which then results in management taking second-best actions (i.e., engaging in NVM behavior). In an empirical test of the model with a sample of $458 \mathrm{BHCs}$, the authors find a non-linear relation between insider shareholdings and risk-taking in lending activity. This relation is similar to the non-linear relation between insider holdings and firm value reported by Morck, Shleifer and Vishny (1988) for their sample of Fortune 500 industrial firms.

Prior research demonstrates the simultaneity of the decisions which management makes regarding debt and dividend policy [Ravid and Sarig (1991)], and the jointness of the relationship between insider holdings, debt and dividend policy [Jensen, Solberg and Zorn (1992)]. The current paper examines the determinants of dividend policy in U.S. BHCs to explain the nature of the relation between insider ownership and the level of dividends. Several recent studies ${ }^{2}$ into the cost of raising capital for banks document the high premium attached to issuing equity capital, not to mention the negative impact of such an action on share value. Thus, rather than a signaling issue, it is possible that the insider owners may decide the level of dividend payout with a desire to increase the value of their shareholdings via lower issuing costs and/or avoiding the negative price impact of share-issuance.

\section{DATA AND METHODS}

Insider holdings data for a sample of BHCs over the period 1994 to 1997 has been collected from Disclosure's CD-ROM files. Each firm was required to have insider holdings data available for at least three of the

Shleifer and Vishny (1989) develop a model of managerial entrenchment. Calomiris and Himmelberg (1999) and Houston et. al. (1997). 
four years of the study period. The financial variables data were collected from the Fire database. All firms were required to have at least three years of data for each of the variables used in the empirical analysis. This additional screen reduced the final sample to 65 BHCs. Table I presents the descriptive statistics for the sample.

Table 1

Given below are the descriptive statistics of the sample of 65 U.S. BHCs. The study period is from 1994-1997. The variable definitions are given below.

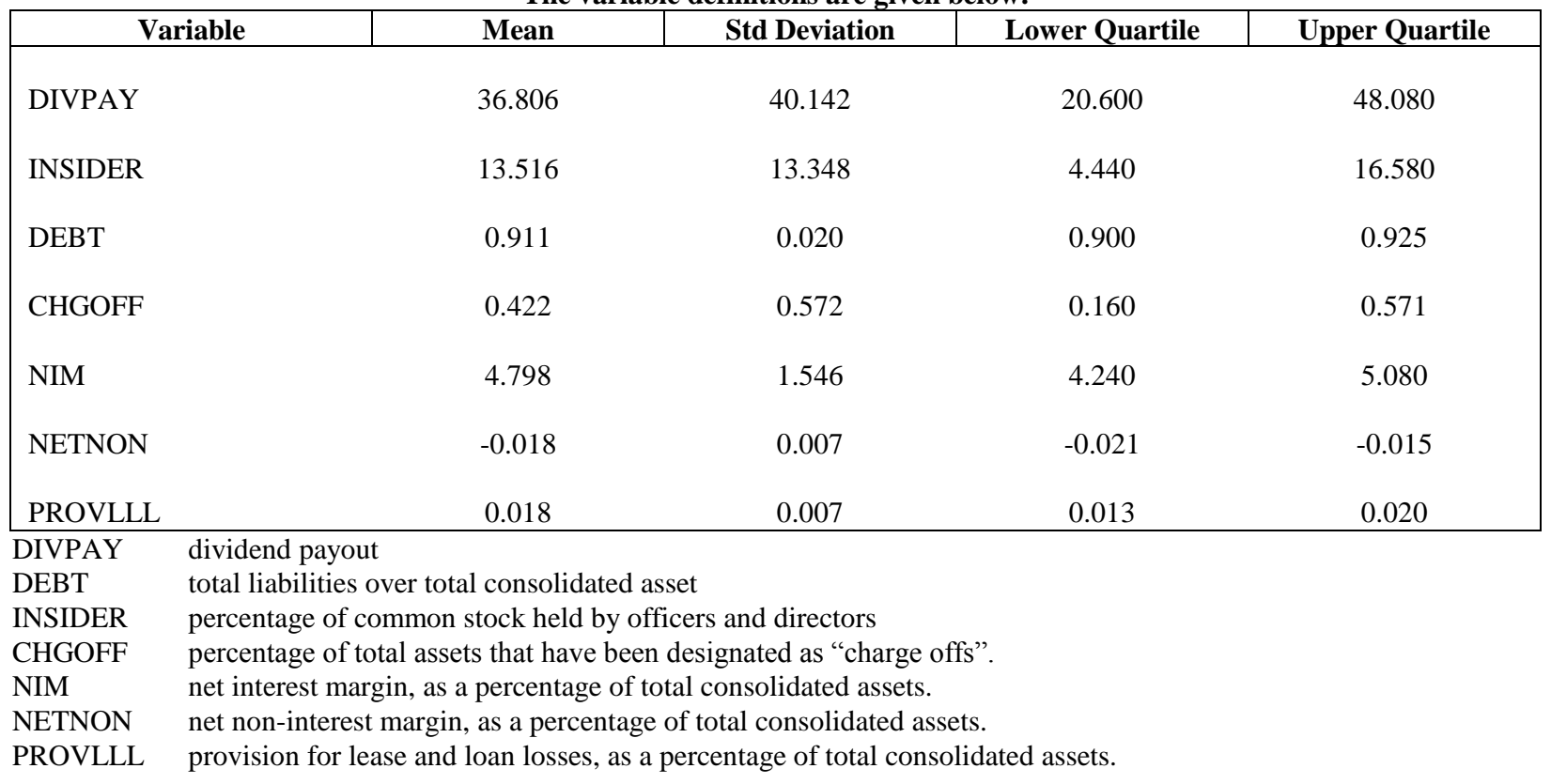

Given that earlier research demonstrates the simultaneity of the decision regarding insider holdings and the level of debt and dividends, this study performs two-stage least square (2SLS) regression. The three dependent variables are DIVPAY (dividend payout), DEBT (total liabilities over total consolidated assets) and INSIDER (percentage of common stock held by officers and directors).

The independent variables included were as follows:

IHSQ the square of insider holdings was included to pick up the non-linearity documented by Gorton and Rosen (1995) in the level of insider holdings and risk-taking activities of BHCs;

SIZE $\quad \log$ of total consolidated assets, as prior studies show that size matters, especially in determining the extent of insider holdings;

PFDDIV this was a binary variable, coded 1 if the BHC paid any preferred dividends, 0 otherwise;

CHGOFF percentage of total assets that have been designated as "charge offs";

NIM net interest margin, as a percentage of total consolidated assets;

NETNON net non-interest margin, as a percentage of total consolidated assets; and

PROVLLL provision for lease and loan losses, as a percentage of total consolidated assets.

\section{RESULTS}

The 2SLS regression is run with three equations, namely DIVPAY, INSIDER and DEBT as the dependent variables. Each of these equation results is shown in Table II. 
Table II

Given below are the results of the two-stage least squares (2SLS) regression analysis with three equations, dividend payout (DIVPAY), insider holdings (INSIDER), and debt (DEBT). Bold indicates that the variable is significant at the $10 \%$ level of significance.

\begin{tabular}{|c|c|c|c|c|c|c|}
\hline & \multicolumn{2}{|c|}{ Equation 1: DIVPAY } & \multicolumn{2}{|c|}{ Equation 2: INSIDER } & \multicolumn{2}{|c|}{ Equation 3: $D E B T$} \\
\hline & Coeff. & T-Stat. & Coeff. & T-Stat. & Coeff. & T-Stat. \\
\hline DIVPAY & & & -0.0348 & -0.81 & -0.0001 & -1.14 \\
\hline INSIDER & -2.8684 & -2.03 & & & -0.0002 & -0.34 \\
\hline DEBT & -325.7140 & -1.14 & 8.4167 & 0.09 & & \\
\hline IHSQ & 0.0513 & 1.87 & & & $5.041 \mathrm{E}-6$ & 0.38 \\
\hline PFDDIV & 13.2337 & 1.13 & 3.2098 & 0.83 & 0.0125 & 2.38 \\
\hline CHGOFF & 51.0850 & 2.84 & -7.6812 & -1.25 & 0.0114 & 1.29 \\
\hline NIM & -7.5589 & -1.11 & 3.7606 & 1.69 & -0.0079 & -2.61 \\
\hline NETNON & -481.1170 & -0.46 & 424.9512 & 1.25 & -0.5294 & -1.10 \\
\hline SIZE & -1.2250 & -0.32 & -3.6434 & -3.17 & 0.0018 & 1.00 \\
\hline PROVLLL & -2993.6100 & -3.12 & 184.1062 & 0.57 & -0.4964 & -1.03 \\
\hline Adj. R-Sq & 0.1486 & & 0.1567 & & 0.2673 & \\
\hline F Value & 2.24 & & 2.49 & & 3.59 & \\
\hline
\end{tabular}

\section{A: Equation 1}

\section{DIVPAY}

There is a significant, negative relation between insider holdings and the level of dividends paid out. This means that a higher level of insider holdings in this sample of U.S. BHCs leads to a significantly lower level of dividend payout. Another result is that the square of insider holdings is seen to be significantly positive. This confirms the non-linearity found by Gorton and Rosen (1995). Their study documents this non-linearity in the level of insider holdings and risk-taking. Our study finds that the non-linearity also extends to the relation between insider holdings and level of dividend payout. So, initially as the level of insider holdings increases, dividend payout is decreasing. However, higher levels of insider holdings lead to greater dividend payout. The first result may be interpreted as firm value maximizing behavior. Given recent research evidence that BHCs pay a heavy premium for raising equity financing, insider holdings may motivate managers to pay less dividends and raise capital requirements via retained earnings. However, if that is the case, interpreting the positive relation at higher levels of insider holdings is more challenging. One interpretation could be that of the free cash flow hypothesis - that when managers cannot identify sufficiently good projects, they would rather pay out available cash as dividends (value maximizing). An alternate interpretation could be that at higher levels of insider holdings, managers become unwarrantedly riskaverse - as they do not wish to lower the value of their own portfolios; hence, this would be NVM behavior.

The only other explanatory variables that are significant in equation one are PROVLLL (provision for lease and loan losses) and CHGOFF (percentage charge off). PROVLLL has a significant negative relation, which is as expected; the higher the amount set aside for potential losses, the less cash is available for paying dividends. CHGOFF has a significant positive relation; one interpretation of this result is that since the uncertainty of making provisions has been resolved, when charge offs are being allocated the available free cash flow for dividends is better known.

\section{B: Equation 2}

\section{INSIDER}

Unlike equation one, in this regression it is seen that the level of dividends has no explanatory power over the level of insider holdings. Thus, allowing for these variables to interact within a simultaneous regression framework shows that, for this sample, the level of dividend payouts is not driving insiders to increase their percentage ownership of the firm. 
As per earlier studies, debt has no impact on insider holdings either. In fact, the only two variables of significance are SIZE (log of total assets) and NIM (net interest margin). SIZE has a negative relation, as is expected. NIM has a positive relation, which supports the notion of higher levels of insider holdings leading to value maximizing behavior, in this instance demonstrated by higher net interest margins on average.

\section{C: Equation 3}

$D E B T$

In the third equation, it is seen that neither dividends nor insider holdings have any relation with debt. The two variables of significance are NIM (net interest margin) and PFDDIV (whether BHC pays any preferred dividends or not). NIM has a negative relation with debt, as is expected; the higher the level of cash inflow, the lower the requirement of raising debt capital. PFDDIV has a positive relation with debt; one interpretation of this result may be that BHCs that have issued preferred stock are less likely to raise equity financing - thus leading to a greater level of debt.

\section{CONCLUSION}

The primary focus of this study was to extend prior research by examining the nature of the relation between insider holdings and its impact on dividend policy for U.S. BHCs. The study examines a sample of 65 BHCs over the period 1994-1997. Simultaneous regression analysis is performed (2SLS) with dividend, insider holdings and debt being the three dependent variables. Size (total assets) seems to be the primary determinant of insider holdings, and net interest margin the most significant variable for the level of debt. In the dividend equation, it is seen that four variables are significant. The level of provision for lease and loan losses has a negative relation whereas the level of charge offs has a positive relation with the level of dividends paid. The most significant result of this study is that the sample finds a significant negative relation between the level of insider holdings and the level of dividends paid, while it also shows that insider holdings has a non-linear relation with dividend payout.

As the level of insider holdings initially increases, dividend payout is decreasing. In view of signaling theory, one may interpret this as substituting one signal of firm quality with another. Also, given recent research evidence that BHCs pay a heavy premium for raising equity financing, insider holdings may motivate managers to pay less dividends and reinvest profits in the bank. Further, one interpretation of the positive relation between dividend payout and insider holdings at higher levels of insider holdings could be that as managers invest more of their wealth in the BHC, they become more risk-averse as they do not wish to lower the value of their own portfolios. Hence, rather than grow the bank via reinvesting earnings, they prefer to pay out free cash flow as dividends.

\section{AUTHOR INFORMATION}

M. Cary Collins, Ph.D. is The Trustee Professor of Entrepreneurship and Director of the Entrepreneurship Program at Bryant University in Smithfield, Rhode Island. Prior to joining Bryant University, Professor Collins held the David Sharp/Home Federal Bank Professorship at The University of Tennessee, Knoxville. Professor Collins holds degrees from Concord University, Virginia Tech, and The University of Georgia.

Amitabh S. Dutta, Ph.D. is an Associate Professor of Finance at The Florida Institute of Technology. Prior to joining The Florida Institute of Technology, Professor Dutta held Assistant \& Associate Professor positions at Columbus State University, as well as an Assistant Professor position at Fairleigh Dickinson University. Professor Dutta holds degrees from the University of Bombay, Wake Forest University, and The University of Tennessee.

James W. Wansley, Ph.D., CFA is the head of the finance department at the University of Tennessee and holds the departments Clayton Homes Chair of Excellence. Prior to joining The University of Tennessee, Professor Wansley held Assistant \& Associate Professor positions at LSU. Professor Wansley holds degrees from Emory University, The University of Georgia, and The University of South Carolina. 


\section{REFERENCES}

1. Bradley, M., G.A. Jarrell and E.H. Kim, 1984, On the existence of an optimal capital structure: Theory and evidence, Journal of Finance 39, 857-878.

2. Calomiris, C.W. and C.P. Himmelberg, 1999, Investment banking costs as a measure of the cost of access to external finance, Working Paper, Columbia University Graduate School of Business, September.

3. Collins, M.C., D.W. Blackwell and J.F. Sinkey Jr., 1994, Financial innovation, investment opportunity and corporate policy choices for large bank holding companies, The Financial Review 29, 223-247.

4. Collins, M.C., D.W. Blackwell and J.F. Sinkey Jr., 1995, The relationship between corporate compensation policies and investment opportunities: Empirical evidence for large bank holding companies, Financial Management 24, 40-53.

5. Gorton, G. and R. Rosen, 1995, Corporate control, portfolio choice, and the decline of banking, Journal of Finance 50, 1377-1420.

6. Healy, P.M. and K.G. Palepu, 1989, How investors interpret changes in corporate financial policy, Journal of Applied Corporate Finance 2, 59-64.

7. Houston, J., C. James and D. Marcus, 1997, Capital market frictions and the role of internal capital markets in banking, Journal of Financial Economics 46, 135-164.

8. Jensen, G.R., D.P. Solberg and T.S. Zorn, 1992, Simultaneous determination of insider ownership, debt, and dividend policies, Journal of Financial and Quantitative Analysis 27, 247-263.

9. Jensen, M.C. and W. Meckling, 1976, Theory of the firm: Managerial behavior, agency costs, and capital structure, Journal of Financial Economics 3, 305-360.

10. McConnell, J. and H. Servaes, 1990, Additional evidence on equity ownership and corporate value, Journal of Financial Economics 27, 595-612.

11. Morck, R., A. Shleifer and R. Vishny, 1988, Management ownership and market valuation: An empirical analysis, Journal of Financial Economics 20, 293-315.

12. Ravid, S.A. and O.H. Sarig, 1991, Financial signaling by committing to cash outflows, Journal of Financial and Quantitative Analysis 26, 165-180.

13. Shleifer, A. and R. Vishny, 1989, Management entrenchment: The case of manager-specific investments, Journal of Financial Economics 25, 123-140.

14. Wruck, K.H., 1989, Equity ownership concentration and firm value: Evidence from privateN equity financings, Journal of Financial Economics 23, 3-28. 